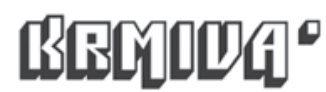

\author{
UTJECAJ DULJINE PROVENJAVANJA NA HRANIDBENU VRIJEDNOST \\ FERMENTIRANE KRME POLUPRIRODNOG TRAVNJAKA
}

\section{THE EFFECT OF THE LENGTH OF WILTING ON THE NUTRITIVE VALUE OF FERMENTED FORAGE FROM SEMI-NATURAL GRASSLAND}

Marina Vranić, K. Bošnjak, Božica Lukšić, Ivana Čačić, G. Šebalj

Izvorni znanstveni članak - Original scientific paper Primljeno - Received: 15. Srpanj - July 2018

\section{SAŽETAK}

Cilj istraživanja bio je utvrditi utjecaj duljine provenjavanja krme poluprirodnog travnjaka zajednice Arrhenatheretum medioeuropaeum ruderale na hranidbenu vrijednost fermentirane krme, kvalitetu fermentacije u silosu i biološke parametre hranjivosti fermentirane krme u hranidbi preživača. Prvi otkos biljne mase poluprirodnog travnjaka je provenut na tlu tijekom $0,3,6$ i 24 sata nakon čega su formirani laboratorijski silosi za svaku duljinu provenjavanja krme odvojeno. Utvrđeno je da se kvaliteta fermentacije u silosu i biološki parametri hranjivosti krme nisu razlikovali između uzoraka fermentirane krme provenute 3 i 6 sati. Provenjavanje krme 24 sata je rezultiralo povećanim udjelom suhe tvari (ST), neutralnih detergent vlakana (NDV), kiselih detergent vlakana (KDV) $(\mathrm{P}<0,05)$, pH vrijednosti, sadržajem fermentirajuće metaboličke energije u metaboličkoj energiji (FME/ME) i faktora konzumacije za goveda te smanjenim sadržaj sirovih proteina (SP), metaboličke energije (ME), probavljivosti organske tvari u suhoj tvari (D-vrijednost) i faktora konzumacije za ovce. Zaključeno je da provenjavanje biljne mase poluprirodnog travnjaka prije siliranja tijekom 24 sata za parametre kvalitete fermentacije u silosu i biološke parametre kvalitete fermentirane krme ima značajnih prednosti u odnosu na direktno siliranje biljne mase bez provenjavanja ili provenjavanje prije siliranja tijekom 3 ili 6 sati. tacije

Ključne riječi: provenjavanje, sjenaža, hranidbena vrijednost, kvaliteta fermen-

\section{UVOD}

Proizvodnja travne silaže korištenjem silo-kombajna za nisku silažu ima svojih prednosti jer se travna masa sprema jednim prohodom stroja. Međutim, ovakvim postupkom je onemogućeno prethodno provenjavanje usjeva, pa se može izgubiti više od $10 \%$ suhe tvari (ST) ocjeđivanjem silažnog soka iz silosa (Vranić, 2007.). Ovisno o tehnologiji proizvodnje silaže i klimatskim prilikama, krma se nakon košnje može provenuti na određenu razinu ST. Tradicionalne tehnike provenjavanja uključuju rastresanje travne mase nakon košnje kroz jedan ili nekoliko prohoda. Svrha provenjavanja je povećanje sadržaja ST i paralelno koncentracije ugljikohidrata topivih u vodi kao preduvjeta dobre fermentacije $u$ silosu, sprječavanje gubitaka hranjivih tvari ocjeđivanjem silažnog soka iz silosa te povećanje konzumacije ST i proizvodnosti životinja (Wilkinson i sur., 1976.), te smanjene gubitke hranjiva proteolizom i deaminacijom amino-kiselina (Hastings, 1972.). Osim toga, s povećanjem sadržaja ST travne mase za siliranje smanjuje se mogućnost nastajanja karakterističnog neugodnog mirisa povezanog s travnom silažom visokog sadržaja vlage. Postoje i jasni ekonomski pokazatelji i argumenti zaštite okoliša koji govore u prilog provenjavanju tj. proizvodnji travne silaže visokog sadržaja ST.

Marina Vranić, prof. dr. sc., e-mail: mvranic@agr.hr, Krešimir Bošnjak, izv. prof. dr. sc., e-mail: kbosnjak@agr.hr, Božica Lukšić, mag. ing., e-mail: bluksic@agr.hr, Ivana Čačić, dipl. ing., e-mail: icacic@agr.hr, Gordan Šebalj, student Sveučilište u Zagrebu Agronomski fakultet, Svetošimunska cesta 25, Zagreb, 
Ako se travna masa prije siliranja provene na sadržaj ST od $30 \%$, konzervirati će se $8-10 \%$ više ST, nego ako se silira direktno, bez provenjavanja. Hastings (1972.) navodi da ukupni gubitci (u polju i nastali siliranjem) opadaju s povećanjem sadržaja ST biljne mase za siliranje do $400 \mathrm{~g} \mathrm{ST} \mathrm{kg}^{-1}$ svježeg uzorka.

Travna masa bi prije siliranja trebala imati minimalno $250 \mathrm{~g} \mathrm{ST} \mathrm{kg}^{-1}$ svježeg uzorka (Van Vuuren i sur., 1995.) ili $280 \mathrm{~g} \mathrm{ST} \mathrm{kg}^{-1}$ svježeg uzorka (Bastiman, 1976.) kako bi bili minimalni ili se potpuno spriječili gubitci hranjivih tvari ocjeđivanjem silažnog soka. Kod siliranja travne mase u valjkaste bale ovijene plastičnom folijom, zelenu masu je prije baliranja potrebito provenuti na viši sadržaj ST nego kod siliranja u «trench» silose. Viši sadržaj ST omogućuje formiranje čvršćih bala, a time i veću količinu ST krme po bali, smanjuje rizik od deformacije bala, pa tako i oštećenja plastične folije prilikom skladištenja (Chamberlain i Wilkinson, 1996.). U ranijim istraživanjima je travna masa silirana u valjkaste bale ovijene plastičnom folijom u fazi vegetativnog porasta imala sadržaj ST $538 \mathrm{~g} \mathrm{~kg}^{-1}$ svježeg uzorka, a u fazi cvatnje $442 \mathrm{~g} \mathrm{~kg}^{-1}$ svježeg uzorka (Van Vuuren i sur., 1999.), a sjenaža lucerne $535 \mathrm{~g} \mathrm{ST} \mathrm{kg}^{-1}$ svježeg uzorka (Vranić i sur., 2018.).

Prolongirano provenjavanje (više od $550 \mathrm{~g} \mathrm{ST} \mathrm{kg}^{-1}$ svježeg uzorka) dovodi do otežanog sabijanja biljne mase u silosu, povećanih mehaničkih gubitaka, povećanih gubitaka respiraciijom, proteolizom i do ograničene fermentacije (McDonald i sur., 1991.). U istraživanju kvalitete travne silaže tijekom dvije sezone zimske hranidbe muznih krava na 19 obiteljskih poljoprivrednih gospodarstava u sjeverozapadnoj Hrvatskoj, Vranić i sur. (2004., 2005.) su utvrdili prosječan viši udio ST u travnim silažama u odnosu na preporučeni za proizvodnju travne silaže dobre kvalitete u istraživačkoj 2003/2004. i 2004./2005. godini (451 g ST kg-1 svježeg uzorka i $447 \mathrm{~g} \mathrm{ST} \mathrm{kg}^{-1}$ svježeg uzorka respektivno) te značajne varijacije sadržaja ST travnih silaža između obiteljskih poljoprivrednih gospodarstava (od 253$575 \mathrm{~g} \mathrm{ST} \mathrm{kg}^{-1}$ svježeg uzorka u istraživačkoj godini 2003./2004., te od 302-583 g kg-1 svježeg uzorka u istraživačkoj godini 2004./2005.). Obzirom na ostale kemijske parametre hranjivosti, autori (Vranić i sur., 2004., 2005.) objašnjavaju viši sadržaj ST istraživanih travnih silaža/sjenaža na OPG-ima SZ Hrvatske primjenom različitih tehnologija proizvodnje te košnjom tratine u kasnijoj fazi fitofenološkog razvoja biljaka.
Ako krma za siliranje ima previsok sadržaj ST, dobra kvaliteta travne silaže se može postići ako se silira jedan sloj neprovenute, pa jedan sloj previše provenute travne mase. Biljni sok iz neprovenutog sloja krme će povećati sadržaj vlage u previše provenutoj krmi. Neprovenuta krma se može dobro zbiti što pogoduje bržem postizanju anaerobnih uvjeta u previše provenutoj travnoj masi (Vranić, 2007.). Osim razine provenjavanja, na gubitak hranjivih tvari i na kvalitetu travne silaže (konzumacija, proizvodnost životinja) značajan utjecaj ima i brzina provenjavanja. Utjecaj brzine provenjavanja na gubitak hranjivih tvari su istražili Zimmer (1980.) i Zimmer i Wilkins (1984.). Autori navode da kod provenjavanja travne mase 24 sata ili manje, gubitak ST normalno iznosi $10-30 \mathrm{~g} \mathrm{~kg}^{-1}$ svježe travne mase, a gubitak ST travne silaže kod prolongiranog provenjavanja može se kretati čak do $130 \mathrm{~g} \mathrm{~kg}^{-1}$ svježe travne mase. Gubici hranjivih tvari prilikom procesa siliranja travne mase su različiti, a prema istraživanjima Zimmera i Wilkinsa (1984.) gubici u polju su veći, a u silosu manji kod provenute u odnosu na neprovenutu siliranu travnu masu.

O utjecaju brzine provenjavanja na proizvodne karakteristike životinja govori istraživanje Pattersona i sur. (1996.) gdje autori zaključuju da muzne krave konzumiraju statistički značajno više ST travne silaže $(+17 \%)$ i proizvode $2.4 \%$ više mlijeka kod hranidbe travnom silažom koja je brzo provenuta (manje od 30 sati) sa $16 \%$ ST na $32 \%$ ST u odnosu na neprovenutu travnu silažu.

Hipoteza ovog istraživanja je da će provenjavanje biljne mase poluprirodnog travnjaka rezultirati većom hranidbenom vrijednošću, kvalitetom fermentacije u silosu i boljim biološkim parametrima hranjivosti travnih silaža/sjenaža.

Cilj ovog rada je bio utvrditi utjecaj duljine provenjavanja krme prije siliranja na hranidbenu vrijednost, kvalitetu fermentacije u silosu i biološke parametre hranjivosti fermentirane krme.

\section{MATERIJALI I METODE RADA}

\section{Pokusna površina}

Istraživanje je provedeno na pokusnim površinama pokušališta Centar za travnjaštvo Sveučilišta u Zagrebu Agronomskog fakulteta smještenog na 638 metara nadmorske visine u Parku prirode Med- 
vednica. Za potrebe ovog istraživanja korišten je prvi otkos krme poluprirodnog travnjaka zajednice Arhenatheretum medioeuropaeum ruderale. Gnojidba pokusnih površina je izvršena mineralnim gnojivima NPK (formulacije 15:15:15) u količini od $500 \mathrm{~kg} \mathrm{ha}^{-2} \mathrm{i}$ KAN u količini od $600 \mathrm{~kg} \mathrm{ha}^{-1}$.

\section{Košnja pokusne površine}

Pokusne parcelice su košene 18.05.2017. kosilicom u početku metličanja dominantnih trava na visinu od $5 \mathrm{~cm}$. Traka širine $1,2 \mathrm{~m}$ košena je po sredini svake osnovne parcelice. Pokošena biljna masa je uzorkovana radi provedbe fizikalnih i kemijskih analiza te ostavljena provenuti na otvorenom. Vrijeme tijekom provenjavanja je bilo sunčano i izrazito toplo $\left(28-29^{\circ} \mathrm{C}\right)$, biljna masa je rastresena po šatorskom krilu držanom na betonu čime je osiguran snažan efekt isparavanja vlage.

\section{Formiranje laboratorijskih silosa}

Biljna masa (200-250 grama) je silirana u laboratorijske silose koristeći vakuum uređaj (SmartVac) i PVC vrećice neposredno nakon košnje (0 bez provenjavanja) ili za 3, 6 i 24 sata nakon košnje. Formirana su po 4 laboratorijska silosa po tretmanu (4 ponavljanja). Laboratorijski silosi su ostavljeni fermentirati 35 dana u zatvorenoj prostoriji na temperaturi od $10^{\circ} \mathrm{C}$ nakon čega su otvoreni i analizirani.

Nakon otvaranja silosa u svakom utvrđenom terminu, uzeti su uzorci biljne mase. Vrijednost $\mathrm{pH}$ je utvrđivana u filtratu dobivenom od cca 10 grama svježe silaže i $100 \mathrm{ml}$ destilirane vode korištenjem pH metra (WTE, model 315i).

Sadržaj ST je utvrđen (AOAC, 1990.) sušenjem uzoraka u sušioniku s ventilatorom (EAS23-030) na temperaturi od $60^{\circ} \mathrm{C}$ do konstantne mase uzorka. Osušeni uzorci su samljeveni na veličinu čestica od $1 \mathrm{~mm}$ korištenjem mlina čekićara tvrtke Christy (Model 11) i dalje korišteni za spektrofotometrijsku analizu. Uzorci su dalje dosušivani minimalno tri sata u sušioniku na temperaturi od $105^{\circ} \mathrm{C}$, zatim hlađeni u eksikatoru 10-ak minuta i punjeni u kivetu (dimenzije 5,0 ×6,5 cm) za skeniranje osušenih i samljevenih uzoraka.

Svi uzorci su u duplikatu skenirani na NIRS aparatu (Foss, model 6500) pomoću infracrvenog elektromagnetskog spektra, u valnoj duljini 1100-
$2500 \mathrm{~nm}$ korištenjem ISI SCAN programa (verzija 1.5 (Infrasoft International, Port Matilda, PA, USA). Spektrima uzoraka su pridružene odgovarajuće kalibracije. S obzirom na prethodno utvrđenu količinu dostavne ST, procijenjeni su sljedeći kemijski parametri hranjivosti: korigirana ST, sirovi proteini (SP), razgradivi SP, neutralna detergent vlakna (NDV), metabolička energija (ME), kiselost $(\mathrm{pH})$, amonijski dušik $\left(\mathrm{NH}_{3}-\mathrm{N}\right)$, šećer i probavljivost OT u ST (D-vrijednost).

\section{Statistička analiza rezultata istraživanja}

Rezultati istraživanja su obrađeni korištenjem statističkog programa SAS (SAS Institut, 1999.) pomoću GLM i MIXED procedure.

\section{REZULTATI I RASPRAVA REZULTATA}

Kvalitetna travna silaža bi prema Chamberlainu i Wilkinsonu (1996.) trebala sadržavati više od $300 \mathrm{~g} \mathrm{ST} \mathrm{kg}^{-1}$ svježeg uzorka, 300-400 g kg-1 korigirane ST (KST), 150-175 g sirovih proteina (SP) kg-1 ST, 4,0-4,5 pH vrijednost, više od 11,00 $\mathrm{MJ} \mathrm{kg}^{-1}$ ST metaboličke energije (ME), više od $70 \%$ fermentirajuće ME (FME) u ME, 500-550 g neutralnih detergent vlakana (NDV) $\mathrm{kg}^{-1} \mathrm{ST}$, manje od $50 \mathrm{~g} \mathrm{~kg}^{-1}$ ST ukupnog dušika u formi $\mathrm{NH}_{3}-\mathrm{N}$, više od $100 \mathrm{~g}$ rezidua šećera $\mathrm{kg}^{-1} \mathrm{ST}$.

U tablici 1 je prikazan utjecaj duljine provenjavanja krme poluprirodnog travnjaka prije siliranja na kemijske parametre hranjivosti fermentirane biljne mase.

Udio ST ( $\mathrm{g} \mathrm{kg}^{-1}$ svježeg uzorka) u ovom istraživanju se povećavao $s$ duljinom provenjavanja od 196,87 $\mathrm{g} \mathrm{kg}^{-1}$ svježeg uzorka (direktno silirana biljna masa) do $531,32 \mathrm{~g} \mathrm{~kg}^{-1}$ svježeg uzorka (biljna masa provenuta $24 \mathrm{~h}$ prije siliranja). Provenjavanje biljne mase 3 sata prije siliranja nije statistički značajno utjecalo $(P>0,05)$ na sadržaj ST fermentirane biljne mase. Provenjavanje biljne mase prije siliranja u trajanju od 6 sati i 24 sata statistički je značajno povećalo sadržaj ST fermentirane biljne mase $(P<0,001)$ u usporedbi s provenjavanjem biljne mase prije siliranja u trajanju od 3 i 0 sati. Biljna masa provenuta 24 sata imala je viši $(P<0,001)$ sadržaj ST u usporedbi s provenjavanjem $u$ trajanju od 6 sati. Trend istovjetan sadržaju ST uzoraka travnih silaža/ sjenaža slijedi i sadržaj korigirane ST. 
Rezultati sadržaja ST nakon provenjavanja u trajanju od 24 sata mogu se usporediti s ranijim istraživanjima gdje je nakon 24 sati provenjavanja lucerne utvrđen sadržaj ST sjenaže od $535 \mathrm{~g} \mathrm{kg-1}$ svježeg uzorka (Vranić i sur., 2018.). Prema utvrđenom sadržaju ST travnih silaža/sjenaža u ovom istraživanju, niti jedna duljina provenjavanja krme poluprirodnog travnjaka prije siliranja nije rezultirala optimalnim sadržajem ST fermentirane biljne mase koji iznosi od 300-380 $\mathrm{g} \mathrm{ST} \mathrm{kg}^{-1}$ svježeg uzorka ili $300-400 \mathrm{~g} \mathrm{~kg}^{-1}$ korigirane ST (KST) (Chamberlain i Wilkinson, 1996.). Optimalan sadržaj ST fermentirane biljne mase bi vjerojatno bio ostvaren sa duljinom provenjavanja između 6 i 24 sata koja ovim istraživanjem nije obuhvaćena.

Sadržaj SP istraživanih tretmana provenjavanja nije se značajno razlikovao između tretmana provenjavanja 0,3 i 6 sati $(P>0,05)$, ali je bio statistički značajno niži kod tretmana provenjavanja krme prije siliranja u trajanju od 24 sata u usporedbi s ostalim razinama provenjavanja krme $(\mathrm{P}<0,05)$. U ranijim istraživanjima (Wilkinson i sur., 1976.) je utvrđeno da s porastom sadržaja ST provenjavanjem krme prije siliranja, koncentracija SP opada te da nakon $26 \mathrm{~h}$ provenjavanja opadanje sadržaja SP je rezultat mehaničkih gubitaka lisne mase. Prema sadržaju SP fermentirane krme porijeklom od svih tretmana provenjavanja sve silaže/sjenaže se uklapaju u optimalne koje bi trebale sadržavati $150-175 \mathrm{~g} \mathrm{SP} \mathrm{kg}^{-1}$ ST (Chamberlain i Wilkinson, 1996.).

Sadržaj ME se značajno smanjio $(P<0,05)$ nakon 24 sata provenjavanja biljne mase prije siliranja u usporedbi s ostalim istraživanim tretmanima provenjavanja krme. Isto se može povezati s povećanjem sadržaja vlakana (NDV i KDV) provenjavanjem koje je bilo značajno više $(\mathrm{P}<0,001$ i $\mathrm{P}<0,05$ odmosno) nakon 24 sata provenjavanja u usporedbi s ostalim istraživanim duljinama provenjavanja. U travnoj silaži su vlakna glavni izvor energije (Phipps i sur., 2000.). O razini njihove razgradnje u buragu preživača ovisi energetska vrijednost krme (NRC, 2001.). Ugljikohidrati se u buragu razgrađuju na hlapive masne kiseline (octena, propionska i maslačna) koje se apsorbiraju kroz stijenku buraga ili tankog crijeva i postaju dostupne životinji kao izvor energije. S porastom sadržaja vlakana u krmi, osobito KDV (većim dijelom neprobavljive stanične stijenke u usporedbi s NDV) smanjuje se razina iskoristive energije krmiva (Vranić, 2007., Vranić i sur., 2008.). Fermentirana krma istraživanih tretmana provenjavanja prije siliranja je sadržavala nešto nižu razinu ME u odnosu na optimalnu u travnim silažama /sjenažama koja iznosi više od $11 \mathrm{MJ} \mathrm{kg}^{-1} \mathrm{ST}$ (Chamberlain i Wilkinson, 1996.), ali je u skladu s očekivanjima hranjive vrijednosti krme poluprirodnog travnjaka.

Tablica 1. Utjecaj duljine provenjavanja krme prije siliranja na hranjivost fermentirane biljne mase (izraženo u g kg-1 ST ako nije drugačije navedeno)

Table 1 The effect of forage wilting length before ensiling on ensiled forage nutritive value (in $\mathrm{g} \mathrm{kg-1} \mathrm{DM} \mathrm{if} \mathrm{nor} \mathrm{stated} \mathrm{otherwise)}$

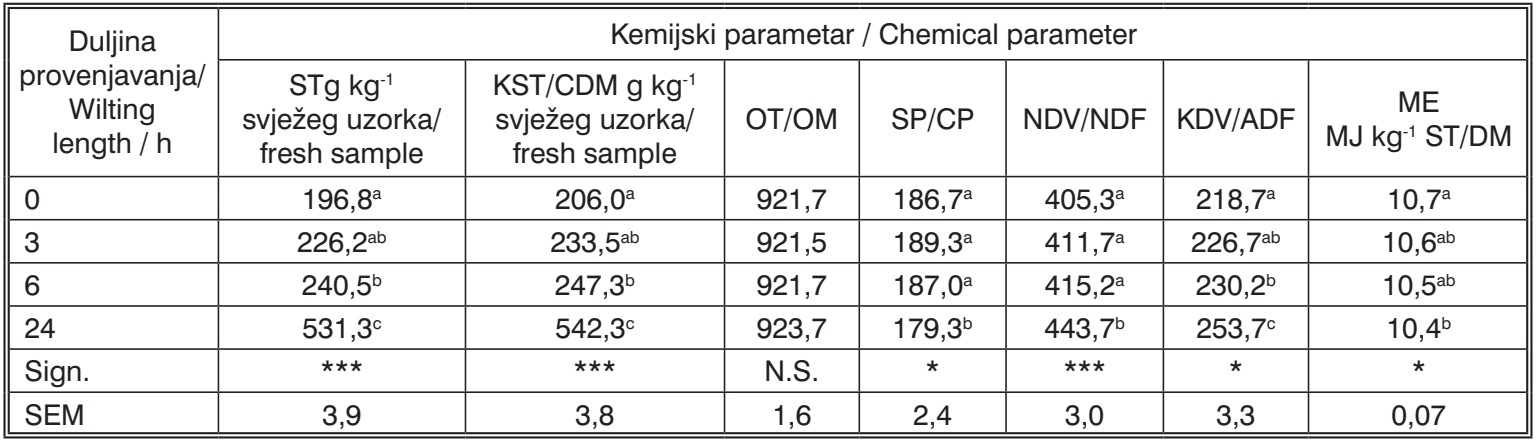

ST, suha tvar, KST, suha tvar korigirana na hlapive komponente uzorka; SP, sirovi proteini, OT, organska tvar; NDV, neutralna detergent vlakna; ME, metabolička energija; KDV, kisela detergent vlakna; 0 , silirano bez provenjavanja; 3 , krma provenuta 3 sata prije siliranja; 6 , krma provenuta 6 sati prije

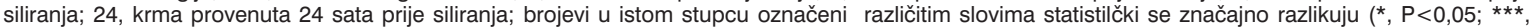
$\mathrm{P}<0,001)$; SEM, standardna greška srednje vrijednosti.

DM, dry matter; CDM, DM corrected for volatile components; CP, crude protein; OM, organic matter; NDF, neutral detergent fibre; ADF, acid detergent fibre; $\mathrm{ME}$, metabolizable energy; 0 , no wilting; 3 , wilted for 3 hours before ensiling; 6 , wilted for 6 hours before ensiling; 24 , wilted for 24 hours before ensiling; numbers in the same column marked with different letters differ $\left({ }^{*}, \mathrm{P}<0,05 ;{ }^{* *}, \mathrm{P}<0,001\right)$; SEM, standard error of the mean. 
U tablici 2 je prikazan utjecaj duljine provenjavanja krme poluprirodnog travnjaka prije siliranja na kvalitetu fermentacije u silosu.

$\cup$ ovom istraživanju je utvrđen najveći udio FME/ME (energije dostupne za iskorištenje mikroorganizmima buraga) za fermentiranu biljnu masu poluprirodnog travnjaka koja je prije siliranja provenuta 24 sata $(P<0,05)$ u usporedbi s ostalim razinama provenjavanja. Sadržaj FME/ME može varirati od $70 \%$ ukupne metaboličke energije (ME) kod loše silaže do 95\% kod koncentrata (Allen, 2001.) prema čemu se sjenaža provenuta 24 sata prije siliranja može svrstati u poželjnu sjenažu.

Najniža pH vrijednost je utvrđena kod siliranja biljne mase bez provenjavanja $(P<0,01)$, između provenjavanja 3 i 6 sati nije bilo razlika u pH vrijednosti fermentirane biljne mase $(P>0,05)$, a provenjavanje 24 sata rezultiralo je najvišom $\mathrm{pH}$ vrijednosti fermentirane krme $(\mathrm{P}<0,01)$.

Sadržaj ST određuje koja će se pH vrijednost postići u siliranoj masi nakon završetka fermentacije. Ranija istraživanja (Wilkinson 1990., Vranić i sur., 2010.) pokazuju da s povećanjem sadržaja ST provenjavanjem raste i $\mathrm{pH}$ vrijednost dobro silirane i stabilne travne silaže. Viša pH vrijednost silaže ne znači da je silaža lošije kvalitete, što je osobito izraženo kod travne silaže spremljene u bale omotane plastičnom folijom, jer se prema Chamberlainu i Wilkinsonu (1996.) travna silaža spremljena na taj način može stabilizirati kod više $\mathrm{pH}$ vrijednosti.
Osim sadržaja ST na razinu do koje će se pH vrijednost spustiti u siliranoj biljnoj masi značajan utjecaj ima i puferni kapacitet biljke, a to je prirodna sposobnost biljnog materijala promjenama $\mathrm{pH}$ vrijednosti, osobito zakiseljavanju. Visina pufernog kapaciteta najviše ovisi o sadržaju organskih kiselina, ortofosfata, nitrata, sulfata, klorida i samo $10-20 \%$ o sadržaju proteina. Prema Thomasu i Fisheru (1991.) kod siliranja travne mase mora se postići kritična razina kiselosti, kako bi se izbjegla nepoželjna fermentacija (razvoj bakterija maslačne kiseline, bakterija trulenja, plijesni), pa pH silaže izvrsne kvalitete može varirati od 3.8 kada je sadržaj ST 15\%, pa do 5.5 ili 5.8 kod sadržaja ST 30-40\%. Ovo potvrđuju i istraživanja Gordona i Murdocha (1978.) u kojima je travna silaža visoke kvalitete imala relativno visok pH (5.0) zbog visokog sadržaja ST travne mase za siliranje (51.4\%).

Kvaliteta fermentacije silaže se osim prema $\mathrm{pH}$ vrijednosti utvrđuje s obzirom na sadržaj pojedinih kiselina (mliječna, octena, maslačna), koncentraciju $\mathrm{NH}_{3}-\mathrm{N}$ i alkohola u silaži (Lyttleton, 1973.). Najniži sadržaj $\mathrm{NH}_{3}-\mathrm{N}$ je utvrđen u fermentiranoj krmi polurirodnog travnjaka koja je provenuta 24 sata prije siliranja $(P<0,05)$ u usporedbi s ostalim tretmanima provenjavanja. Navedeno je u suglasju $s$ istraživanjima Hendersona i sur. (1982.) koji su utvrdili da se povećanjem sadržaja ST silaže smanjuje sadržaj $\mathrm{NH}_{3}-\mathrm{N}$ i raste sadržaj proteinskog $\mathrm{N}$.

Tablica 2. Utjecaj duljine provenjavanja krme poluprirodnog travnjaka prije siliranja na kvalitetu fermentacije u silosu

Table 2 The effect of of semi-natural grass wilting length before ensiling on the fermentation quality of ensiled forage

\begin{tabular}{||l|c|c|c|c||}
\hline \multirow{2}{*}{$\begin{array}{c}\text { Duljina provenjavanja } \\
\text { Wilting length /h }\end{array}$} & \multicolumn{3}{|c|}{ Parametar kvalitete fermentacije u silosu/ Fermentation quality parameter in silo } \\
\cline { 2 - 5 } & FME/ME & $\mathrm{pH}$ & $\begin{array}{c}\mathrm{NH}_{3}-\mathrm{N} \mathrm{g} \mathrm{N} \mathrm{kg}^{-1} \\
\text { ukupnog/total N }\end{array}$ & $\begin{array}{c}\text { Rezidui šećera /sugar residues } \\
\text { g kg-1 ST/DM }^{-1}\end{array}$ \\
\hline 0 & $0,73^{\mathrm{a}}$ & $4,52^{\mathrm{a}}$ & $132,00^{\mathrm{a}}$ & $99,50^{\mathrm{a}}$ \\
\hline 3 & $0,76^{\mathrm{b}}$ & $4,80^{\mathrm{b}}$ & $149,25^{\mathrm{b}}$ & $93,00^{\mathrm{ab}}$ \\
\hline 6 & $0,76^{\mathrm{b}}$ & $4,77^{\mathrm{b}}$ & $154,25^{\mathrm{b}}$ & $85,50^{\mathrm{b}}$ \\
\hline 24 & $0,84^{\mathrm{c}}$ & $5,45^{\mathrm{c}}$ & $123,00^{\mathrm{c}}$ & $91,25^{\mathrm{ab}}$ \\
\hline Sign. & $*$ & $\star \star$ & $*$ & ${ }^{\mathrm{b}}$ \\
\hline SEM & 0,005 & 0,05 & 2,30 & 3,71 \\
\hline
\end{tabular}

FME/ME, fermentirajuća metabolička energija u metaboličkoj energiji; NH3-N, ammonium nitrogen; 0 , silirano bez provenjavanja; 3 , krma provenuta 3 sata prije siliranja; 6 , krma provenuta 6 sati prije siliranja; 24, krma provenuta 24 sata prije siliranja; brojevi u istom stupcu označeni različitim slovima statistilčki se značajno razlikuju (*, $\mathrm{P}<0,05 ; * \star, P<0,01)$; SEM, standardna greška srednje vrijednosti.

FME/ME, fermented metabolic energy in metabolic energy ; NH3-N, ammonium nitrogen; 0 , no wilting; 3 , wilted for 3 hours before ensiling; 6 , wilted for 6 hours before ensiling; 24 , wilted for 24 hours before ensiling; numbers in the same column marked with different letters differ ( $\left.{ }^{*}, \mathrm{P}<0,05 ;{ }^{\star *}, \mathrm{P}<0,01\right)$; $\mathrm{SEM}$, standard error of the mean. 
Najviši sadržaj rezidua šećera je utvrđen u direktno siliranoj biljnoj masi $(P<0,05)$ u usporedbi s ostalim istraživanim tretmanima provenjavanja biljne mase prije siliranja. Poželjno je da nakon fermentacije biljne mase u silosu ostane što veći udio rezidua šećera u ST fermentirane krme. Rezidui šećera su brzi i lako dostupan izvor energije za mikrobe buraga, a osobito su značajni kod hranidbe preživača krmom bogatom lako topivim proteinima u buragu (sjenaža). U nedostatku energije u obroku, $\mathrm{N}$ ne mogu iskoristiti mikrobi buraga za svoj rast i razvoj nego se izluči iz organizma te ostaje neiskorišten i za mikrobe i za životinju.

$U$ tablici 3 je prikazan utjecaj duljine provenjavanja krme poluprirodnog travnjaka prije siliranja na biološke parametre hranjivosti fermentirane biljne mase.

Hashemzadeh-Cigari i sur. (2011.) navode da je opadanje probavljivosti krme provenjavanjem ovisno o duljini i brzini provenjavanja. Probavljivost fermentirane krme opada od 2,3 do $9,0 \mathrm{~g} \mathrm{~kg}^{-1}$ ST nakon 10-satnog provenjavanja. Poznato je da brzina sušenja biljne mase ovisi o trajanju i intenzitetu sunčeve svjetlosti i prinosu biljne mase po jedinici površine, pa autori (Hashemzadeh-Cigari i sur., 2011.) zaključuju da krmu treba provenuti u što kraćem vremenskom roku kako bi se minimaliziralo opadanje probavljivosti krme.
Probavljivost organske tvari (OT) u ST (D-vrijednost) je opala sa $67,25 \%$, koliko je iznosila kod fermentirane krme silirane bez provenjavanja, na $65 \%$ kod fermentirane krme provenute 24 sata prije siliranja $(P<0,001)$, ali se svi istraživani tretmani prema D-vrijednosti mogu svrstati u fermentiranu krmu dobre kvalitete jer im je D-vrijednost viša od $65 \%$ (Chamberlain i Wilkinson, 1996.).

Faktor konzumacije za goveda (FK-goveda) govori o potencijalnoj preferenciji goveda, odnosno ovaca za krmom prikazane hranjivosti. Izračun se temelji na tjelesnoj masi goveda preračunatoj na metaboličku tjelesnu masu $\left(\mathrm{M}^{0,75}\right)$. Faktor konzumacije 100 govori o prosječnoj preferenciji goveda prema krmi.

Vidljivo je da bi goveda preferirala krmu koja je provenuta 24 sata prije siliranja gdje je i utvrđen statistički značajno veći faktor konzumacije za goveda $(\mathrm{P}<0,05)$ u usporedbi s ostalim istraživanim tretmanima provenjavanja krme prije siliranja. Suprotno, ovce bi preferirale krmu koja je silirana direktno, bez provenjavanja, u prilog čemu govori statistički značajno veći faktor konzumacije za ovce $(P<0,05)$ fermentirane biljne mase koja nije provenuta u usporedbi s ostalim istraživanim tretmanima provenjavanja krme prije siliranja.

Tablica 3. Utjecaj duljine provenjavanja krme poluprirodnog travnjaka prije siliranja na biološke parametre hranjivosti fermentirane biljne mase

Table 3 The effect of semi-natural forage wilting length before ensiling on ensiled forage biological nutritive parameters

\begin{tabular}{||l|c|c|c||}
\hline \multirow{2}{*}{$\begin{array}{c}\text { Duljina Provenjavanja / } \\
\text { Wilting lenght / }\end{array}$} & \multicolumn{3}{|c||}{ Biološki parametar hranjivosti krme/ Biological feeding parameter } \\
\cline { 2 - 4 } & $\begin{array}{c}\text { D-vrijednost/ D-value } \\
(\%)\end{array}$ & FK-goveda/IF-cattle & FK- ovce/IF sheep \\
\hline 0 & $67,25^{\mathrm{a}}$ & $95,00^{\mathrm{a}}$ & $132,25^{\mathrm{a}}$ \\
\hline 3 & $66,50^{\mathrm{ab}}$ & $99,75^{\mathrm{b}}$ & $123,50^{\mathrm{b}}$ \\
\hline 6 & $65,75^{\mathrm{b}}$ & $101,75^{\mathrm{b}}$ & $120,75^{\mathrm{b}}$ \\
\hline 24 & $65,00^{\mathrm{b}}$ & $125,75^{\mathrm{c}}$ & $104,25^{\mathrm{c}}$ \\
\hline Sign. & $\star \star \star$ & $\star$ & $*$ \\
\hline SEM & 0,44 & 1,19 & 2,55 \\
\hline
\end{tabular}

D-vrijednost, probavljivost organske tvari u suhoj tvari; 0 , silirano bez provenjavanja; 3 , krma provenuta 3 sata prije siliranja; FK-goveda, factor konzumacije za goveda; FK-ovce, factor konzumacije za ovce; 6 , krma provenuta 6 sati prije siliranja; 24, krma provenuta 24 sata prije siliranja; brojevi u istom stupcu označeni različitim slovima statistilčki se značajno razlikuju (*, $\mathrm{P}<0,05$; $* \star \star, P<0,001)$; SEM, standardna greška srednje vrijednosti.

D-value, digestibility of the organic matter in the dry matter;IF-cattle, intake factor for cattle; IF-sheep; intake factor for sheep; 0 , no wilting; 3 , wilted for 3 hours before ensiling; 6 , wilted for 6 hours before ensiling; 24 , wilted for 24 hours before ensiling; numbers in the same column marked with different letters differ $\left({ }^{*}, \mathrm{P}<0,05 ;{ }^{* *}, \mathrm{P}<0,01\right)$; SEM, standard error of the mean. 
Provenjavanje krme prije siliranja ima neke od prednosti u usporedbi sa siliranjem biljne mase bez provenjavanja: (i) niži su troškovi transporta krme (ne prevozi se voda koja nema energetsku vrijednost), (ii) štedi se skladišni prostor jer se bale mogu uskladištiti jedna na drugu, (iii) nema gubitaka hranjiva ocjeđivanjem silažnog soka, (iv) osigurava se bolji supstrat za siliranje radi akumuliranih jednostavnioh šećera u biljnoj masi tijekom provenjavanja (Vranić, 2007.).

\section{ZAKLJUČAK}

Zaključeno je da provenjavanje biljne mase poluprirodnog travnjaka prije siliranja tijekom 24 sata za parametre kvalitete fermentacije u silosu i biološke parametre kvalitete fermentirane krme ima značajnih prednosti u odnosu na direktno siliranje ili provenjavanje prije siliranja tijekom 3 ili 6 sati.

\section{LITERATURA}

1. Allen, D. (2001.): Rationing beef cattle. Chalcombe Publications, Painshall, Church Lane, Welton, Lincoln, UK.

2. AOAC (1990.): Official methods of the association of analytical chemists, Vol. 2, 15th Edition. AOAC, Arlington, Virginia, USA.

3. Bastiman, B. (1976.): Factors affecting silage effluent production. Experimental Husbandry 1976, 31, 1-32.

4. Chamberlain, A.T., Wilkinson, J.M. (1996.): Feeding the Dairy Cow. Chalcombe Publications, PainShall, Ln2 3LT, UK.

5. Gordon, F.J., Murdoch, J.C. (1978.): An evaluation of a high-quality grass silage for milk production, Journal of the British Grassland Society, Volume 33, 5-11.

6. Hashemzadeh-Cigari F., Khorvash M., Ghorbani G. R., Taghizadeh A. (2011.): The effects of wilting, molasses and inoculants on the fermentation quality and nutritive value of lucerne silage. South African Journal of Animal Science, 41, 4, 377-388.

7. Hastings, M. (1972.): Investigations into bunker ensilage at Experimental Husbandry Farms and elsewhere during the last decade. ADAS Quarterly Review, 5, 1-11.

8. Henderson, A.R., McDonald, P., Anderson, D.H. (1982.): The effect of silage additives containing formaldehyde on the fermentation of ryegrass ensiled at different dry-matter levels and on the nutritive value of direct-cut silage. Animal feed Science and Technology, 7, 303-314.
9. Lyttleton, W.J. (1973.): Protein and Nucleic Acids, 63-103. In: Butler, G.W. and R.W. Bailey (eds.): Chemistry and Biochemistry of Herbage. Academic Press London.

10. McDonald, P., Henderson, A.R., Heron, S.J.E. (1991.): The biochemistry of silage, $2^{\text {nd }}$ edn. Marlow, UK: Chalcombe Publications, 82-122. Pattersona i sur. (1996.).

11. National Research Council (NRC) (2001.): Nutrient Requirements of Dairy Cattle. Seventh Revised Edition 2001. National Academic Press, Washington, D.C., $381 \mathrm{pp}$.

12. Phipps, R.H., Sutton, J.D., Beever, D.E., Jones, A.K. (2000.): The effect of crop maturity on the nutritional value of maize silage for lactating dairy cows. 3. Forage intake and milk production. Animal Science, 71, 401-409.

13. SAS (1999.). SAS ${ }^{8}$ Software, SAS Institute Inc., Cary, North Carolina, USA.

14. Thomas, C., Fisher, G. (1991.): Forage conservation and winter feeding. In Thomas, C., Reeve, A., Fisher, G.E.J. (eds.) Milk from Grass. ICI, SAC, IGER, 2nd edn. 27-51. British Grassland Society, Reading.

15. Van Vuuren, A.M., Huhtanen, P., Dulphy, J.P. (1995.).: Improving the feeding and health value of ensiled forages. In: M.Journet, E.Grenet, M.-H. Farce, M.Theriez, C.Demarquilly, Editors, Recent developments in the Nutrition of Herbivores, Proceedings of the IV th International Symposium on the Nutrition of Herbivores, INRA Editions, Paris (1995.): pp. 279-307.

16. Van Vuuren, A.M., Klop, A., van der Koelen, C.J., De Visser, H. (1999.): Starch and stage of maturity of grass silage: Site of digestion and intestinal nutrient supply in dairy cows. Journal of Dairy Science, 82, 143-152.

17. Vranić, M., Knežević, M., Perčulija, G., Leto, J., Bošnjak, K., Rupić, I. (2004.): Kvaliteta voluminozne krme na obiteljskim poljoprivrednim gospodarstvima u Republici Hrvatskoj. Kvaliteta travne silaže na obiteljskim poljoprivrednim gospodarstvima. Mljekarstvo 54(3):165-174.

18. Vranić, M., Knežević, M., Leto, J., Perčulija, G., Bošnjak, K., Kutnjak, H., Maslov, L. (2005.): Kvaliteta voluminozne krme na obiteljskim poljoprivrednim gospodarstvima u Republici Hrvatskoj: Monitoring kvalitete travne silaže tijekom dvije sezone zimske hranidbe muznih krava. Mljekarstvo 55(4): 283-296.

19. Vranić, M. (2007.): Konzerviranje krme. Proizvodnja silaže. Interna skripta za studente. Sveučilište u Zagrebu Agronomski fakultet. 
20. Vranić, M., Knežević, M., Bošnjak, K., Leto, J., Perčulija, G. Matić, I. (2008.): Effects of replacing grass silage harvested at two maturity stages with maize silage in the ration upon the intake, digestibility and $\mathrm{N}$ retention in wether sheep. Livestock Science, 114, 1; 84-92.

21. Vranić, M., Knežević, M., Bošnjak, K., Perčulija, G., Leto, J., Kutnjak, H., Lujanac, M. (2010.): Hranjivost travnih silaža bazirana na sadržaju suhe tvari. Poljoprivreda (Osijek), 16, 2; 42-46.

22. Vranić, M., Grbeša, D., Bošnjak, K., Mašek, T., Jareš, D. (2018.): Intake and digestibility of sheep-fed alfalfa haylage supplemented with corn. Canadian Journal of Animal Science, 98, 1; 135-143.
23. Wilkinson, J.M., Wilson, R.F., Barry, T.N. (1976.): Factors affecting the nutritive value of silage. Outlook on Agriculture, 9, 3-8.

24. Wilkinson, J.M. (1990.): Silage UK. Sixed edition. Chalcombe Publications. 167 pp.

25. Zimmer, E. (1980.): Efficient silage systems. Forage conservation in the 80's. In: Proceedings of the European Grassland Federation. Occasionalo Symposium No. 11, Brighton, 186-197.

26. Zimmer, E., Wilkins, R.J. (1984.): Efficiency of silage systems: a comparison between unwilted and wilted silages. Eurowilt. Sonderheft 69. Institute of Grassland and Forage Research, Braunschweig - Volkenrode, Germany.

\section{SUMMARY}

The objective of this paper was to determine the effect of wilting forage originating from semi-natural grassland Arrhenatheretum medioeuropaeum ruderal community, prior to ensiling on the nutritive value, fermentation quality and biological parameters of fermented forage in ruminant nutrition. The first cut of seminatural grassland was wilted over 0, 3, 6 and 24 hours before ensiled in laboratory siloses that were formed for each wilting lenght separately. The fermentation quality and biological parameters did not differ between fermented forage wilted over 3 and 6 hours prior ensiling. Forage wilting over 24 hours prior to ensiling resulted in increased concentration of dry matter (DM), neutral detergent fibre (NDF), acid detergent fibre (ADF), pH values, fermenting metabolic energy in metabolic energy (FME/ME) and intake factor for cattle and reduced crude protein (CP), metabolic energy (ME), digestibility of organic matter in the dry matter (D-value) and intake factor for sheep. It was concluded that wilting of semi-natural forage over 24 hours prior to ensiling improved fermentation quality in the silo and the biological parameters of fermented forage in comparison with direct ensiling or wilting over 3 or 6 hours prior to ensiling.

Keywords: wilting, haylage, nutritive value, fermentation quality 